UDC $801.7+122 / 129$

DOI https://doi.org/10.32841/2409-1154.2020.46-1.10

\author{
Biriukova D. V., \\ Candidate of Philological Sciences, \\ Associate Professor at the Department of Foreign Philology, Translation \\ and Professional Language Training \\ University of Customs and Finance
}

\author{
Tsvietaieva O. V., \\ Candidate of Social Communications Sciences, \\ Associate Professor at the Department of English Language for Non-Philological Specialities \\ Oles Honchar Dnipro National University
}

Znanetska O.M., Candidate of Psychological Sciences, Associate Professor at the Department of English Language for Non-Philological Specialities Oles Honchar Dnipro National University

\title{
THE ANALYSIS OF CONCEPTS USED IN INTERIOR DESCRIPTIONS
}

Summary. The article analyzes the conceptual space of intratextual descriptions (ID) of the interior in the English literary discourse. It is established that conceptual space is a relatively open system, its elements are concepts of different content and purpose, interconnected by hierarchical and linear relationship and the integrating principle is the concept idea "interior", which is implemented using concepts that embody space features as "objectivity" and "three-dimensionality" and form two corresponding clusters. The objective of the article is to clarify the features of the conceptual space of intranet descriptions of the interior, which involves solving such tasks as understanding the concept of "conceptual space", isolating and modeling the configurations of the mental units that serve the implementation of the concept idea "interior". The authors urge that linguistic analysis and modeling of mental representations are based on the postulate of cognitive science on the existence of a determinant link between structured mental content and the corresponding linguistic forms. As for studying the cognitive aspect of the intratextual interior description (ID), the linguistic layer (semiotic structure) of the descriptive texts is understood as the key to their conceptual content, and the interface between them is the frame ID as a cognitive proposal model for organizing knowledge about a stereotyped situation. That's why the frame correlates the language and cognitive elements of the ID with each other, fixing the existing correlations. Therefore, the linguistic units, established by means of semiotic analysis of the ID, induce the key concepts for these texts, the totality of which forms their conceptual space. It is stressed that linguocultural concepts can be understood as mental units that reflect the established notions of substantive entities, their visual features and value for a particular language community, while linguistic and cognitive concepts will be construed as embodying the idea of spatial relationships between these subject entities and having a reduced form of imagery and value components. The combination of the first forms the cluster "subject", the other one forms the cluster "dimension".

Key words: conceptual space, description of interior, concept, cluster, cognitive mechanisms
Problem statement. Intratextual interior descriptions (ID) are the fragments of English-language artistic discourse, which global task is to create a visual image of the room in the reader's imagination. The achievement of this goal is possible due to the existence of a stable cognitive structure of descriptive texts, which reconstruction and modeling involves the study of the conceptual space of intrastate interior descriptions.

Linguistic analysis and modeling of mental representations are based on the postulate of cognitive science on the existence of a determinant link between structured mental content and the corresponding linguistic forms, because "anguage is the system of adaptation, which is formed in the process of cognitive activity of a man, the tool of this process, as well as the most important way of the formation and presentation of knowledge" [4, c. 121].

To study the cognitive aspect of the intratextual ID, this statement means that the linguistic layer (semiotic structure) of the descriptive texts is the key to their conceptual content, and the interface between them is the frame INTERIOR DESCRIPTION as a "cognitive proposal model for organizing knowledge about a stereotyped situation " [2, c. 104] The frame correlates the language and cognitive elements of the ID with each other, fixing the existing correlations. Therefore, the linguistic units, established by means of semiotic analysis of the OI, induce the key concepts for these texts, the totality of which forms their conceptual space.

The main goal of this article is to clarify the features of the conceptual space of intranet descriptions of the interior, which involves solving such tasks as understanding the concept of "conceptual space", isolating and modeling the configurations of the mental units that serve the implementation of the concept idea "“interior". The object of the research is the description of the interior in the English-language art discourse of the XIX-XX centuries. The subjects of the research are the concepts that embody spatial signs.

The concept of "conceptual space" still did not have a high demand in the linguistic literature, in contrast to the actual concept, which is its direct constituent. The scope of its terminological construction is limited to several studios that interpret it according to 
their original installation - cognitive-linguistic or cognitive-poetic ones. In the first case, the term "conceptual space" is considered as a special type of organization of concepts in the human consciousness and the linguistic picture of the world - the integrity, which includes all the environments of one or another concept, the sphere of its existence, both in a separate language consciousness and within the linguistic picture of the world, and is determined by the fact that the actualization of one of the concepts inevitably implies the actualization of the other one [2, c. 104]. This point of view, of course, has the right to exist, but it is somewhat redundant in view of the presence of the term "conceptual field" [7, p. 176], which is fixed as a designation of the described mental structure.

The representatives of the cognitive-poetic approach often use the term "conceptual space" as a synonym for "conceptual sphere". Not only the fact of their synonymic use, but also the application of the latter to the designation of the mental space of the artistic work in general seem to be erroneous, since traditionally the conceptosphere is understood as "an ordered set of concepts of the people, an information base of thinking" [6, p. 26]. However, in spite of this inaccuracy, that is inherent in this approach of the conceptual space as a mental unity, that "embraces the general meaning and basic senses" of an artistic work [11, p. 173], fully corresponds to the logic of this study.

Conceptual space of the text is formed at the highest level of abstraction on the basis of merging, convergence, pulling of common features of concepts represented at the surface level by words and sentences of one semantic field [1, p. 58]. The key cognitive structure of this space is the concept idea, which is the "condensation of the embodied author's idea" - a set of macroproposals that reflect the basic essence of the semantic array of text [8, p. 196].
The conceptual space of the intratextual ID is a relatively open system: its elements are concepts of different content and purpose, interconnected by hierarchical and linear relations (pic. 1). The concept-idea INTERIOR is the integral part of this conceptual space. Being a "shortened" model of discourse or its fragment, in which all possible potential realizations are latent "in which all possible potential implementation are latently presented" [5, p. 70], is materialized in the intrantextual ID by means of more specific spatial concepts room, house and apartment.

Unlike the abstract conceptual idea interior, mental units room, house and apartment which are related according to the conceptual basis of "closed inner space" have a defined shaped ("structure", "accommodation", "residence") and value components ("family comfort", "privacy", "comfort").

The concept ROOM plays a special role in the intrantextual ID, which reflects the idea of a segment of space, which can, due to its size, become the object of direct observation, and hence, the description. In addition, it is distinguished by a more detailed linguistic elaboration, which manifests itself in the presence of a large group of tokens formed on the composite word-building model. It is based on the nomination of action that occurs in one or another room (sitting-room, dressing-room, breakfast-room, dining-room, drawing-room, waiting-room, store-room, lecture-room). This enables the explicit differentiation of the space according to its functional purpose.

Scattered in spatial concepts ROOM, HOUSE, and APARTMENT, the concept INTERIOR reflects "the location of objects in the world continuum and their positions relative to each other" $[10$, c. 3]. Implementation of this conceptual idea requires the involvement of mental units that embody spatial signs of objectivity and three-dimensionality.

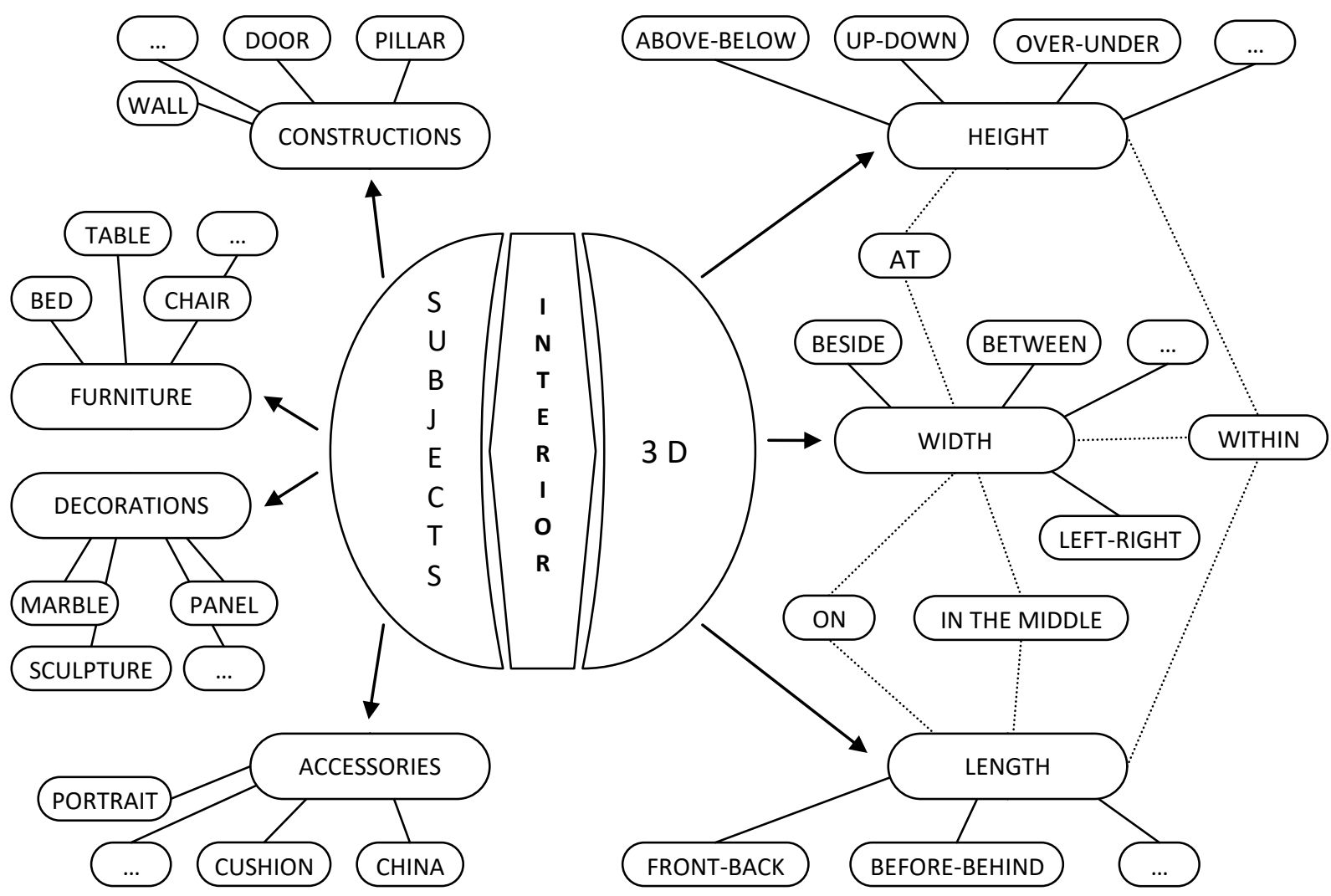

Fig. 1. Conceptual space of intratextual interior descriptions 
"Subject" and "spatial" elements of the ID conceptual space are fundamentally different in content. In the absence of more successful terms, it is legitimate to indicate them conventionally as linguocultural and linguocognitive, accordingly. Unlike the proposed by V.I. Karasik opposition of these concepts by the criterion of the carrier (subject) of knowledge - collective or individual one [3, c. 74], in the framework of this study, they will differ in the nature and content of their three-component structure (concept, image, evaluation).

Linguocultural concepts will be understood as mental units that reflect the established notions of substantive entities, their visual features and value for a particular language community, whereas linguistic and cognitive concepts will be interpreted as embodying the idea of spatial relationships between these subject entities and having a reduced form of imagery and value components. The combination of the first ones forms the cluster SUBJECT, the other ones form the cluster DIMENSION.

Subject linguistic and cultural concepts are "concepts-artifacts" $[8$, p. 247] - metal units that reflect the idea of artificially created material objects that fill the room and thus create its interior. In their combination they form a cluster of SUBJECT, the integral idea of which is "substance". This constant conceptual feature, presented in the structure of each concept of this grouping, is specified by the differential features of "design", "furniture", "decoration" and "accessories", motivated by the functional purpose of the corresponding interior objects.

Concepts-artifacts that have a common sign of "construction" are the largest part of the SUBJECT cluster and reflect the notion of architectural elements of the apartment - constructional (CEILING, FLOOR, WALL), functional (DOOR, STAIRS, WINDOW) and decorative (ALCOVE, BALUSTRADE, COLONNADE, FIREPLACE, PILLAR, STAIRS) ones. Since the main parts of the structure and their functions are quite universal, the concepts of the first two types show a slight variability, while the relatively high frequency in the ID. The others represent the aesthetic research in the planning of the premises, related to the tastes and preferences of their owners, so they are significantly more numerous, although they have a low individual performance in the ID.

The cognitive sign "furniture" combines the concepts that capture the mental images of the objects of the room environment. These include, in particular, BED, MANTELPIECE, SIDEBOARD, SOFA, TABLE, WARDROBE, etc., the updating of which in the ID allows the reader to form his own idea of the place of action deployed in the work, as well as to identify the premises for a functional purpose, if the text does not express it explicitly.

Unlike concepts that contain the differential sign of "constructs", the number of which is objectively limited by physical laws and architectural traditions, the list of concepts, united by the sign of "furniture" and capable of being implemented in the texts of artistic ID, is fundamentally open and depends on the creative method and the idea of the author.

The cognitive sign "decoration" is common to mental units that reflect the idea of a variety of decorative design options: decoration materials (brass, mahogany, marble, oak, silk, wood), finishing works (mosaics, ornament, panel, relief) and enrichments (trophy, sculpture). These concepts show low productivity in the intratextual IDs, because the objects represented by them, in contrast to the structural elements of the room or furniture, are optional means of interior design. That is why their implementation in the ID is not automatic and serves to implement a certain intention of the author.
According to the functions performed by them in the intratextual ID, such "mental" units are similar to "decorative" concepts cushion, doll, jar, picture etc., combined by a cognitive feature "accessories". They concentrate on the idea of small things, minor details that complement the overall picture of the interior. Of all subject concepts, they depend most on the storyline of a particular work, determined by it, and therefore, in essence, are conceptual variables of intratextual ID. This explains their great variety, irregularity of actualization and very low productivity.

Spatial linguistic and cognitive concepts reflect the notion of a way of co-existence of material objects embodied in subject concepts. Their integrating beginning is the THREE-DIMENSION (TRIMINITY) idea, which unites them into a cluster of the same name. As the objective property of reality, THREE-DIMENSION (TRIMINITY) represents "the cognitive mechanisms underlying the perception and cognition of the human being of the world" $[10$, c. 8$]$, and in particular, the correlation of the perceived order of existence of objects with one of three dimensions - height, width or length. The latter are the conceptual features that mark the affiliation of each individual spatial concept to the corresponding group within the cluster of THREE-DIMENSION (TRIMINITY).

The cognitive sign "height" is realized by the opposition of the concepts top - bottom, which reproduces the location of interior elements on the vertical axis "top-down". The results of the study devoted to the methods of verbalization of the concept SPACE LOCALIZATION in English language linguistics indicate that the recognition of a person by the vertical position of objects is a priority prototype of the perception of spatial coordinates, because due to the peculiarities of anatomical structure of a person its vertical position is extra-hunted to the substantive essence [10, c. 8]. The analysis of the semiotic structure of the intranet ID does not confirm these conclusions - the performance of the actant-partmones to indicate the vertical coexistence of objects is low.

The cognitive sign "width" concentrates the idea of the horizontal arrangement of objects along the lateral axis "left - right" and is embodied in the binary opposition of the concepts LEFT - RIGHT. The latter marks the extreme points of the horizontal spectrum, which allow the presence of an intermediate position "between". The low productivity of these mental units in the intranet ID is explained with the peculiarities of the visual perception of a person: his attention is attracted, first of all, by the objects located in the center of the field of view, while things that are on its periphery are fixed only if they are of special importance or of unusual nature.

The cognitive sign "length" is reproduced by the binary opposition of the concepts front - back, which reflects the front axle "front-back". The analysis of the semiotic structure of the intratextual ID shows them somewhat higher discursive significance compared to left - right, since "under canonical conditions, the movement of a person in space takes place in a straight line, which coincides with the vector of the direction of view, because the safety of movement in space directly correlates with the volume of information received" $[10$, p. 9]. Actants and partonymes that verbalize the opposition front - back, object the whole spectrum of the corresponding spatial values: "front -back" (front - back, before behind, beyond), "along" (lengthways), "opposite" (against, vis- $a$ vis), "at a distance" (aloof, apart). However, as well as the linguistic representatives of other spatial concepts, they do not express any appreciable connotations that would give reason to draw conclusions about the nature of the narratives of these mental units. 
The highest productivity in intratextual IDs has an idea of the spatial relationship between objects formed through the conceptual integration - "the basic cognitive mechanism of conceptual mixing necessary for storing and operating diffuse values" $[12$, c. 57]. Such mental constructions - blends - arise at the intersection of concepts that reflect different spatial axes. They are not identical to any of the original elements and do not equal their amount, instead they receive a new value of their own [9].

Spatial relations that arise at the intersection of the vertical and lateral horizontal axes are fixed by the partonym at, which points to the vertical position of several objects located near, close to each other. In the texts under study at serves as a means of localizing a character in the context of an intratextual ID and the knowledge of its position, and indicates the interior items extending from the "top to bottom" axis. At theintersection of the lateral and frontal axes there are two spatial blends which are embodied by actants-partonyms on (upon) and in the middle (in the center). The first actualizes the signs in direct contact with the surface, surface supported and indicates the location of the object in a horizontal plane without specifying its position relatively to the perceiving subject ("left right" or "front - behind").

The cognitive signs "on the surface", "in direct contact with the surface" allow the partmony on to signal the location of the interior of the interior in a vertical plane, first of all, on the wall. In this case, the representation of the blend formed by the integration of representations of the vertical and lateral axis takes place. The difference between $a t$ and on is determined by the distance between the objects - small and zero ones, respectively.

Actant and partonym in the middle and its variant in the center determine the exact location of the object of the interior, since they mark directly the point of intersection of both horizontal axes. The obligatory condition of the actualization of this spatial blend is the reference to another subject or a segment of the interior space, in the center of the horizontal surface of which the object of attention is localized.

The conceptual blend created by crossing all three spatial axes vertical, lateral and frontal ones - embodies the idea of three-dimensionality in its entirety, as it concentrates the meaning "inside", which directly correlates with the idea of the interior as a segment of the closed, internal space. It discovers the highest discursive activity and finds the incarnation in the intratextual ID by the means of actant-partonyms like in, inside of, through, within etc., as well as by way of parallel updating of partonyms to designate all spatial measurements.

Summing up, we note that the integrating beginning of the conceptual space of intrastate interior descriptions is a concept-idea interior, which is realized with the help of concepts, that embody the spatial signs of "objectivity" and "three-dimensionality" and form two corresponding clusters.

The cluster SUBJECT is formed by a set of linguistic and cultural subject concepts, which integral element is a sign of "substance", and differential ones - "construction" (wall, ceiling, floor), "furniture" (table, bed, chair), "decor" (marble, sculpture) and "accessories" (picture, cushion). Their actualization and performance entirely depend on the creative intention of the author, and the detailed elaboration of figurative and value components not only makes them "building material" of intrastate descriptions of the interior, but also illustrates the linguistic and cultural specificities of the latter.
Linguocognitive spatial concepts, which totality forms a cluster THREE-DIMENSIONALITY, are differentiated by the notional features of "height", "width" and l"ength". Each sign corresponds to one of the spatial dimensions and subordinates the corresponding binary opposition, which represents a spatial axis - vertical (TOP BOTTOM), lateral (LEFT - RIGHT) or frontal one. The highest productivity in the intratextual interior descriptions reveals the conceptual blends, created by the mental integration of representations of all three spatial axes and represented by partonyms in, inside of, through, within. The intramedical descriptions of the interior do not include any evidence of the peculiarities of the value perception of spatial relationships or ethnocultural reasons caused by the differences in their conceptualization.

The study of the use of stylistic tools and techniques when representing the interior in artistic discourse is considered to be prospective for further research.

\section{References:}

1. Бабенко Л.Г. Лингвистический анализ художественного текста. Теория и практика / Л. Г. Бабенко, Ю. В. Казарин. Москва : Флинта : Наука, 2003. 496 с.

2. Ефремов В.А. Теория концепта и концептуальное пространство. Известия Рос. гос. пед. ун-та имени А.И. Гериена. 2009. № 104. С. 96-106.

3. Карасик В.И. Этноспецифические концепты. Введение в когнитивную лингвистику / 3.Д. Попова, И.А. Стернин, В.И. Карасик, А.А. Кретов, О.О. Борискина, Е.А. Пименов, М.В. Пименова / Под ред. М.В. Пименовой. Кемерово : Кузбасвузиздат, 2005. С. 61-105.

4. Костюшкина Г.М. Концептуальная систематика языка, речи и речевой деятельности как объект лингвистики. Концептуальный анализ языка. Современные направления исследования : сборник научных трудов. Москва : РАН. Институт языкознания, 2007. C. 119-129.

5. Олешков М.Ю. Лингвоконцептуальный анализ дискурса (теоретический аспект). Дискурс, концепт, жанр : коллективная монография / Отв. ред. М.Ю. Олешков. Нижний Тагил : НТГСПА, 2009. С. $68-85$.

6. Попова З.Д. Когнитивная лингвистика / З.Д. Попова, И.А. Стернин. Москва : АСТ: Восток-Запад, 2007. 314 с.

7. Приходько А.Н. Концепты и концептосистемы. Днепропетровск : Белая Е.А., 2013. 307 c.

8. Селиванова Е.А. Основы лингвистической теории текста и коммуникации. Киев : Фитосоциоцентр, 2002. 336 с.

9. Скребцова Т.Г. Языковые бленды в теории концептуальной интеграции Ж. Фоконье и М. Тернера. Respectus Philologicus. 2002. № 2(7). URL: http://filologija.vukhf.lt/2-7/skrebcova.htm.

10. Скрынникова И.В. Вербализация концепта «пространственная локализация» в англоязычной лингвокультуре : автореф. дис. ... канд. филол. н. : 10.02 .04 «Германские языки» / Волгоградск. гос. ун-т. Волгоград, 2004. 22 с.

11. Швачко С.О. Концептуальний підхід до структурних одиниць текстів: контрастивні аспекти / С.О. Швачко, І.К. Кобякова, Т.О. Анохіна. Вісник СумДУ. Серія Філологія. 2007. № 2. С. 173-178.

12. Fauconnier G. Conceptual Blending, Form, and Meaning / G. Fauconnier, M. Turner. Cognitive Semiotics, special issue of Recherches en Communication. 2004. № 19. P. 57-86.

Бірюкова Д.В., Цвєтаєва О.В., Знанецька О.М. Аналіз конщептів, що використовуються в описах інтер'сру

Анотація. Стаття присвячена аналізу концептуального простору інтратекстових описів інтер'єру в англомовному літературно-художньому дискурсі. Встановлено, що 
концептуальний простір являє собою порівняно відкриту систему: їі елементами є концепти різного вмісту й призначення, пов'язані між собою ієрархічними та лінійними відношеннями, а інтегруючим началом є концепт-ідея «interior», яка реалізується за допомогою концептів, що втілюють просторові ознаки 'предметність' і 'тримірність', та утворюють два відповідних кластери. У роботі зазначається, що інтратекстові описи інтер'єру є фрагментами англомовного художнього дискурсу, глобальним завданням яких є створення візуального образу приміщення в уяві читача. Досягнення цієї мети уможливлюється завдяки наявності сталої когнітивної структури описових текстів, реконструкція та моделювання якої передбачають дослідження концептуального простору інтратекстових описів інтер'єру. Стверджується, що лінгвістичний аналіз і моделювання ментальних репрезентацій спираються на постулат когнітивної науки про наявність детермінуючого зв'язку між структурованим ментальним змістом і відповідними мовними формами. Тому для вивчення когнітивного аспекту інтратекстових описів інтер'єру це твер- дження означає, що мовний шар (семіотична структура) описових текстів $\epsilon$ ключем до їх концептуального змісту, а єднальною ланкою між ними виступає саме фрейм «опис інтер'єру». Підкреслюється, що мовні одиниці, встановлені шляхом семіотичного аналізу опису інтер'єру, індикують ключові для цих текстів концепти, сукупність яких і формує їх концептуальний простір. Автори стверджують, що сфера термінологічного побутування поняття «концептуальний простір» обмежується кількома студіями, які витлумачують його згідно зі своєю вихідною установкою когнітивно-лінгвістичною чи когнітивно-поетичною. Термін «концептуальний простір» розглядається як особливий тип організації концептів у людській свідомості та мовній картині світу - цілісність, яка включає в себе все оточення того чи іншого концепту, сферу його існування як в окремій мовній свідомості, так і в межах мовної картини світу, і визначається тим, що актуалізація одного 3 концептів неминуче передбачає актуалізацію іншого.

Ключові слова: концептуальний простір, опис інтер'єру, концепт, кластер, когнітивні механізми. 